\title{
Comparative Study of Synthesis and Spectral Studies of Thiophenyl Carboxylate Derivatives by Microwave Irradiation and Conventional Method
}

\author{
M. R. EZHILARASI ${ }^{*}$ and B. PRABHA \\ Department of Chemistry, Karpagam University, Coimbatore-641021, Tamilnadu, India \\ mrezhilarasi@gmail.com
}

Received 10 July 2015 / Accepted 24 July 2015

\begin{abstract}
A simple and novel synthesis of series carboxylates derivatives were synthesized by reacting different substituted thiophene-2yl-1-arylprop-3-ene-1-one (chalcones) with ethylacetoacetate in the presence of acid medium. The synthesis was carried out by conventional methods. The synthesized compounds have been monitored by TLC and characterized by elemental analysis, IR, ${ }^{1} \mathrm{H}$ NMR, ${ }^{13} \mathrm{C}$ NMR spectroscopy. The synthesised compounds were checked by their drug ability. The drug ability of the compounds was confirmed by Lipinski's Rule (Rule 5).
\end{abstract}

Keywords: Thiophene Chalcone, Ethylacetoacetate, Acetic acid, Carboxylate derivatives, Microwave irradiation

\section{Introduction}

Chalcones (trans-1, 3-diaryl-2-propen-1-ones) (1), a biosynthetic product of the shikimate pathway, belonging to flavanoid family are precursors of open chain flavonoids and is flavonoids, which are abundant in edible plants. Chalcones are also key precursors in the synthesis of many biologically important heterocycles such as benzothiazepine, pyrazolines, 1, 4-diketones and flavones. Thus the synthesis of chalcones has generated vast interest to organic as well as for medicinal chemists. A group of compounds having different substitution patterns on the two aromatic rings of 1, 3 diphenyl-2-propen-1-one which is known as chalcone and it is linked by a three carbon $\alpha, \beta$-unsaturated carbonyl system. It is an important class of natural product and belongs to the flavonoid family which have been reported a wide spectrum of biological activities including anti-inflammatory, antimutagenic, anti-bacterial and anti-fungal. They are also defined as the product of condensation of substituted or simple aromatic with substituted or simple acetophenones in the presence of alkali. Some of the derivatives of chalcones are used as drugs, sunscreen agents and sweeteners. A growth of interest is growing now-a-days in exploiting more than one proximal functional pharmacophoric groups for designing novel structures capable of performing a variety of functions. One of the essential components of the search for new leads 
in drug designing programme is to synthesis molecules, which are novel still resembling known biologically active molecules by virtue of the presence of some critical pharmacophoric structural features. The motive for the preparation of highly functionalized cyclohexenone ethyl carboxylates is due to the fact that they are excellent carriers of different types of biological activity. Cyclohexenoic long chain fatty alcohols are used in the treatment of neurological disorders. Ambuic acid, a highly functionalized cyclohexenones exhibits antifungal activity. Jesterone and hydroxyl jesterone are highly functionalized cyclohexeneyl ester derivatives with potent antifungal activity.

The use of microwave heating was introduced by the groups Gedye and Giguere/Majetich in 1986 seems first application in organic synthesis. Although many of the early pioneering experiments in microwave-assisted synthesis have been carried out in domestic microwave ovens, the trend since year 2001 undoubtedly is to use dedicated microwave reactors specifically designed for synthetic applications or controlled microwave synthesis. The latest equipments afford more reproducible results. These instruments feature built-in magnetic stirrers, direct temperature control of the reaction mixture with the aid of internal fiber-optic probes or external infrared sensors, and software that enables on-line temperature/pressure control by regulation of microwave power output. Controlled microwave irradiation under sealed vessel conditions has been shown to dramatically reduce reaction times, increase product yields and to enhance product purity by reducing unwanted side reactions compared to conventional synthetic methods. Though, microwave introduction in day to day life was cover past several years. Microwave (MW) irradiation, an unconventional energy source, has been used for a variety of applications including organic synthesis, wherein chemical reactions are accelerated because of selective absorption of MW energy by polar molecules, non polar molecules being inert to the MW dielectric loss. Heterogeneous reactions have attracted attention from two decades to avoid the use of well known pollutant such as volatile organic compounds (VOCs). The application of microwave irradiation in conjunction with the use of catalysts or mineral-supported reagents, under solvent-free conditions, enables organic reactions to occur expeditiously at ambient pressure, thus providing unique chemical processes with special attributes such as enhanced reaction rates, higher yields and the associated ease of manipulation. In the following section, selective efforts of various research chemists on solid state-MWI enhanced MCRs are described.

The traditional methods for the synthesis of 1,3-diaryl-2-propenones involves the use of strong bases such as $\mathrm{NaOH}, \mathrm{KOH}, \mathrm{Ba}(\mathrm{OH})_{2}$, hydrotalcites, LiHMDS, calcined $\mathrm{NaNO}_{3}$ /natural phosphate. There are also some reports of acid-catalyzed aldol condensations, e.g. $\mathrm{AlCl}_{3}, \mathrm{BF}_{3}$, dry $\mathrm{HCl}, \mathrm{ZrH}_{2} / \mathrm{NiCl}_{2}$ and $\mathrm{RuCl}_{3}$ (for cyclic and acyclic ketones). Chalcones and its derivatives have attracted increasing attention due to numerous pharmacological applications. They have displayed a broad spectrum of pharmacological activities, among which antimalarial ${ }^{1-4}$, antifungal ${ }^{5,6}$, antimicrobial ${ }^{7}$, larvicidal ${ }^{8}$, anticonvulsant ${ }^{9}$, antioxidant ${ }^{10-12}$ activities. The IR spectrum supported the data showing the characteristic band for $\mathrm{C}=\mathrm{O}$ at 1645 to 1655 and $\mathrm{C}=\mathrm{C}$ at around 1570 to $1600 \mathrm{~cm}^{-1}$ and aromatic $\mathrm{CH}$ band between 3000 to $3100 \mathrm{~cm}^{-1}$ and aliphatic $\mathrm{CH}$ band stretching between 2900 to $3000 \mathrm{~cm}^{-1}$ and band for the C-S group is in the range of 600 to $800 \mathrm{~cm}^{-1}$. The IR spectra of these compounds revealed a sharp strong absorption band above $1730 \mathrm{~cm}^{-1}$ that can be correlated with the presence of the ester function in the structure of cyclohexanones and for the aliphatic $\mathrm{CH}$ group showed a sharp absorption band around $2900 \mathrm{~cm}^{-1}$ and aromatic $\mathrm{CH}$ group showed a sharp absorption band around $3100 \mathrm{~cm}^{-1}$, another sharp strong absorption band was noticed at approximately $1590-1660 \mathrm{~cm}^{-1}$. 
Moreover, the interesting starting material, 2-thiophenecarboxaldehyde is used as an intermediate to manufacture pharmaceuticals and aroma compounds. In the present work chalcones have been prepared according to Claisen-schimidt condensation by condensing 2-thiophenecarboxaldehyde with substituted ketones. These chalcone derivatives were reacted with ethyl aceto acetate $(2 \mathrm{mmol})$ to form ethyl- 4-(thiophen-2-yl)-2-oxo-6- aryl cyclohex-3-ene carboxylates. The structures of the synthesized compounds were elucidated on the basis of their elemental analysis, FT-IR, one dimensional ${ }^{1} \mathrm{H}$ and ${ }^{13} \mathrm{C}$ spectroscopic data.

\section{Experimental}

The starting materials, thiopene -2- carboxaldehyde was purchased from Sigma Aldrich. All the reagents were of analytical grade. Thin-layer chromatography (TLC) was performed on E.Merck AL silica gel 60 F254 plates and visualized under Iodine. The IR spectra were recorded on a Perkin Elmer FT-IR spectrometer. The ${ }^{1} \mathrm{H}$ NMR and ${ }^{13} \mathrm{C}$ NMR spectra are recorded at $400 \mathrm{MHz}$ and $100 \mathrm{MHz}$ NMR spectrometer(Bruker Biospin International, Ag, Aegeristrasse, Switzerland) using $\mathrm{CDCl}_{3}$ as solvent. All the chemical shift were reported in $\delta$ (ppm) using TMS as an internal standard. All reaction carried out below under room temperature.

\section{General synthesis of thiophene -2yl - 1-H aryl prop-3 ene -1- ones chalcones (1-4)}

The one mole thiophene-2-carboxaldehyde, one mole of various substituted acetophenone was taken in a beaker and to this approximately added $30 \mathrm{~mL}$ of ethanol containing $2 \mathrm{~g}$ of $\mathrm{NaOH}$ pellets. This mixture is stirred well for 30 minutes in an ice cold bath then it was poured into the crushed ice and this reaction was kept overnight at room temperature. The chalcones were precipitated out as solid. Then it was filtered. Dried and re-crystallized. The purity of the sample was checked by TLC by using chloroform as the solvent. IR (KBr): $v_{\max }$ 3066.82, 2931.8, 1653 and $1585.49 \mathrm{~cm}^{-1}$. MS: $\mathrm{m} / z 214(\mathrm{M}+)$.

Synthesis of ethyl 4-(thiophen-2yl)-2-oxo-6 aryl cyclohex-3-ene carboxylates by convectional method (5-8)

A mixture of various substituted thiopene chalcones, ethyl aceto acetate $(2 \mathrm{mmol}), \mathrm{NaOH}$ in dthanol $25 \mathrm{~mL}$ were taken in a dry round bottom flask, the mixture was shaken well and then it was refluxed for 3 hours. The reaction was monitored by TLC. After the reaction mixture was cooled to room temperature and poured into crushed ice, the white precipitate was obtained. After filtration, the precipitate was recrystallised from Ethanol.

General synthesis of ethyl 4-(Thiophen-2yl)-2-oxo-6 aryl cyclohex-3-ene carboxylates by Microwave assisted method (5-8)

A mixture $(0.01 \mathrm{~mol})$ of chalcone derivative and ethyl aceto acetate in alkaline medium viz. in sodium hydroxide $(0.003 \mathrm{~mol})$ in the presence of ethanol $(10 \mathrm{~mL})$. The entire reaction mixture was microwave irradiated at 180 watts for 3-16 minutes and then kept aside for 2-3 $\mathrm{h}$ and resulted formation of carboxylate derivatives. The chemical profile of the compounds is as shown in Table 1.

Synthesis of ethyl 4-(thiophen-2yl)-2-oxo-6 aryl cyclohex-3-ene carboxylates (5)

IR (KBr): $\max 3066.82,2931.8,1732.80,1653$ and $1585.49 \mathrm{~cm}^{-1} .{ }^{1} \mathrm{H}$ NMR $\left(\mathrm{CDCl}_{3}, 400\right.$ $\mathrm{MHz}),(\mathrm{J} \quad \mathrm{Hz})$ ppm:1.30 (3H,t, $\mathrm{CH}_{2} \mathrm{CH}_{3}$ at $\left.\quad \mathrm{C}-1, \mathrm{~J}=7.2 \mathrm{~Hz}\right), \quad 3.04-2.98 \quad\left(2 \mathrm{H}, \mathrm{H}_{5 \mathrm{a}}, \mathrm{m}\right), 3.29-3.24$ $(1 \mathrm{H}, \mathrm{H} 5 \mathrm{e}, \mathrm{m}), 3.70-3.66\left(1 \mathrm{H}, \mathrm{H}_{6}, \mathrm{~m}\right), 3.56-3.40\left(4 \mathrm{H}, \mathrm{m}, \mathrm{CH}_{2} \mathrm{CH}_{3}\right.$ at $\left.\mathrm{C}-1\right), 4.17(1 \mathrm{H}, \mathrm{H} 1, \mathrm{~d}, \mathrm{~J}=14 \mathrm{~Hz})$, $6.39\left(1 \mathrm{H}, \mathrm{d}, \mathrm{H}_{3}, \mathrm{~J}=2.5 \mathrm{~Hz}\right), 7.66-7.08\left(8 \mathrm{H}, \mathrm{m}, \mathrm{Ar} \mathrm{Hs}\right.$ and thiophene protons). ${ }^{13} \mathrm{C}$ NMR (100 
MHz)ppm: 61.3(C-1 carbon),197.80(C-2 Carbon),122.38(C-3 Carbon),155.24 (C-4 Carbon), 35.46(C-5 Carbon), 39.19(C-6 Carbon), 169.24(Ester Carbonyl Carbon), 63.7(Ester Methylene Carbon), 14.10(Ester Methyl Carbon),130.5-126.00(Ar and Thiophene Carbons), 136.6(Ipso Carbons). Elemental analysis data: Calculated for $\mathrm{C}_{19} \mathrm{H}_{18} \mathrm{SO}_{3}: \mathrm{C}=69.93, \mathrm{H}=5.52, \mathrm{~S}=9.81$, $\mathrm{O}=14.72$; Found: $\mathrm{C}=69.89, \mathrm{H}=5.43, \mathrm{~S}=9.78, \mathrm{O}=14.67$. MS: $\mathrm{m} / \mathrm{z} 326(\mathrm{M}+)$.

Table 1. Physical and analytical data of compounds (1-8)

\begin{tabular}{|c|c|c|c|c|c|}
\hline \multirow[t]{9}{*}{ Compound structure } & 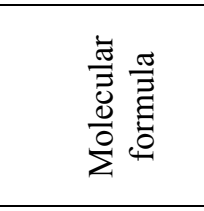 & 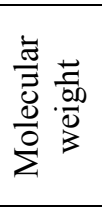 & 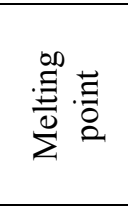 & 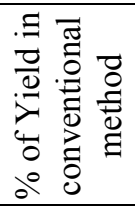 & 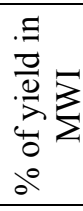 \\
\hline & $\mathrm{C}_{13} \mathrm{H}_{10} \mathrm{SO}$ & 214 & $50{ }^{0} \mathrm{C}$ & $80 \%$ & - \\
\hline & $\mathrm{C}_{13} \mathrm{H}_{9} \mathrm{SOBr}$ & 293 & $130{ }^{0} \mathrm{C}$ & $70 \%$ & - \\
\hline & $\mathrm{C}_{14} \mathrm{H}_{13} \mathrm{SO}$ & 229 & $80{ }^{0} \mathrm{C}$ & $90 \%$ & - \\
\hline & $\mathrm{C}_{14} \mathrm{H}_{12} \mathrm{SO}_{2}$ & 244 & $100{ }^{0} \mathrm{C}$ & $95 \%$ & - \\
\hline & $\mathrm{C}_{19} \mathrm{H}_{18} \mathrm{SO}_{3}$ & 326 & $90{ }^{\circ} \mathrm{C}$ & $50 \%$ & $75 \%$ \\
\hline & $\mathrm{C}_{19} \mathrm{H}_{18} \mathrm{O}_{3} \mathrm{SBr}$ & 406 & $80{ }^{\circ} \mathrm{C}$ & $69 \%$ & $87 \%$ \\
\hline & $\mathrm{C}_{20} \mathrm{H}_{21} \mathrm{O}_{3} \mathrm{~S}$ & 341 & $130{ }^{\circ} \mathrm{C}$ & $70 \%$ & $92 \%$ \\
\hline & $\mathrm{C}_{20} \mathrm{H}_{21} \mathrm{SO}_{4}$ & 357 & $100{ }^{0} \mathrm{C}$ & $73 \%$ & $95 \%$ \\
\hline
\end{tabular}


Synthesis of ethyl 4-(thiophen-2yl)-2-oxo-6 bromophenyl cyclohex-3-ene carboxylates (6)

IR (KBr) cm ${ }^{-1}: 3066.82,2988.30,1734.01,1647.21$ and $1631.78 \mathrm{~cm}^{-1} .{ }^{1} \mathrm{H}$ NMR $\left(\mathrm{CDCl}_{3}, 400\right.$ $\mathrm{MHz}),(\mathrm{J} \mathrm{Hz})$ ppm:1.17 (3H,t, $\mathrm{CH}_{2} \mathrm{CH}_{3}$ at $\left.\mathrm{C}-1, \mathrm{~J}=7.2 \mathrm{~Hz}\right), 3.29-3.24 \quad(1 \mathrm{H}, \mathrm{H} 5 \mathrm{e}, \mathrm{m}), 3.04-2.98$ $\left(2 \mathrm{H}, \mathrm{H}_{5 \mathrm{a}}\right), 3.70-3.68\left(1 \mathrm{H}, \mathrm{H}_{6}, \mathrm{~m}\right), 3.87-3.84\left(4 \mathrm{H}, \mathrm{m}, \mathrm{CH}_{2} \mathrm{CH}_{3}\right.$ at $\left.\mathrm{C}-1\right), 4.17(1 \mathrm{H}, \mathrm{H} 1, \mathrm{~d}, \mathrm{~J}=14 \mathrm{~Hz})$, $6.54\left(1 \mathrm{H}, \mathrm{d}, \mathrm{H}_{3}, \mathrm{~J}=2.5 \mathrm{~Hz}\right), 7.56-6.94 \quad\left(8 \mathrm{H}, \mathrm{m}, \mathrm{Ar} \mathrm{Hs}\right.$ and thiophene protons). ${ }^{13} \mathrm{C} \mathrm{NMR}$ (100MHz)ppm: 60.90(C-1 carbon), 193.19 (C-2 Carbon), 122.38(C-3 Carbon), 157.64 (C-4 Carbon), 36.36(C-5 Carbon), 39.19(C-6 Carbon) 169.24(Ester Carbonyl Carbon), 55.45(Ester Methylene Carbon), 14.04(Ester Methyl Carbon), 129.57-124.38(Ar and thiophene Carbons), 144.73(Ipso Carbons). Elemental analysis data: Calculated for $\mathrm{C}_{19} \mathrm{H}_{18} \mathrm{O}_{3} \mathrm{SBr}: \mathrm{C}=56.17, \mathrm{H}=4.43, \mathrm{O}=11.82, \mathrm{~S}=7.88, \mathrm{Br}=19.70$; Found: $\mathrm{C}=56.11, \mathrm{H}=4.23$, $\mathrm{S}=7.78, \mathrm{Br}=19.61 . \mathrm{MS}: \mathrm{m} / \mathrm{z} 406(\mathrm{M}+)$.

Synthesis of ethyl 4-(Thiophen-2yl)-2-oxo-6 methylphenyl cyclohex-3-ene carboxylates (7)

IR (KBr) cm ${ }^{-1}: 3066.82,2988.30,1734.01,1647.21$ and $1631.78 \mathrm{~cm}^{-1} .{ }^{1} \mathrm{H}$ NMR $\left(\mathrm{CDCl}_{3}, 400\right.$ $\mathrm{MHz}),(\mathrm{J} \mathrm{Hz})$ ppm: $1.28\left(3 \mathrm{H}, \mathrm{t}, \mathrm{CH}_{2} \mathrm{CH}_{3}\right.$ at $\left.\mathrm{C}-1, \mathrm{~J}=7.2\right), \quad 3.20-3.15 \quad\left(2 \mathrm{H}, \mathrm{H}_{5 \mathrm{a}}, \mathrm{m}\right) \quad 3.32-3.389$ $(1 \mathrm{H}, \mathrm{H} 5 \mathrm{e}, \mathrm{m}), 3.82-3.77\left(1 \mathrm{H}, \mathrm{H}_{6}, \mathrm{~m}\right), 3.92-3.39\left(4 \mathrm{H}, \mathrm{m}, \mathrm{CH}_{2} \mathrm{CH}_{3}\right.$ at $\left.\mathrm{C}-1\right), 4.14(1 \mathrm{H}, \mathrm{H} 1, \mathrm{~d}, \mathrm{~J}=14), 6.38$ $\left(1 \mathrm{H}, \mathrm{d}, \mathrm{H}_{3}, \mathrm{~J}=2.5\right), 7.72-6.84(8 \mathrm{H}, \mathrm{m}, \mathrm{Ar} \mathrm{Hs}$ and thiophene protons), 2.07(Methyl at phenyl ring). ${ }^{13} \mathrm{C}$ NMR (100MHz) ppm: 60.06(C-1 carbon), 192.98 (C-2 Carbon), 125.44(C-3 Carbon), 156.47 (C-4Carbon), 36.32(C-5 Carbon),43.02(C-6 Carbon)168.48(Ester Carbonyl Carbon),60.82(Ester Methylene Carbon), 14.14(Ester Methyl Carbon),130.32-128.26(Ar and thiophene Carbons),144.32,136.42(Ipso Carbons), 21.32(Methyl at phenyl ring). Elemental analysis data: Calculated for $\mathrm{C}_{20} \mathrm{H}_{21} \mathrm{O}_{3} \mathrm{~S}: \mathrm{C}=70.38, \mathrm{H}=6.15, \mathrm{O}=14.07, \mathrm{~S}=9.38$; Found: $\mathrm{C}=70.28, \mathrm{H}=6.01, \mathrm{O}=14.01, \mathrm{~S}=9.24$. MS: $\mathrm{m} / \mathrm{z} 341(\mathrm{M}+)$.

Synthesis of ethyl 4-(Thiophen-2yl)-2-oxo-6 methoxyphenyl cyclohex-3-ene carboxylates $(\mathbf{8})$

IR $(\mathrm{KBr}) \mathrm{cm}^{-1}: 3068.82,2988.30,1732.22,1646.23$ and $1634.78 \mathrm{~cm}^{-1} .{ }^{1} \mathrm{H}$ NMR $\left(\mathrm{CDCl}_{3}\right.$, $400 \mathrm{MHz}),(\mathrm{J} \mathrm{Hz})$ ppm:1.17 $\left(3 \mathrm{H}, \mathrm{t}, \mathrm{CH}_{2} \mathrm{CH}_{3}\right.$ at $\left.\mathrm{C}-1, \mathrm{~J}=7\right), \quad 3.08-3.01 \quad\left(2 \mathrm{H}, \mathrm{H}_{5 \mathrm{a}}, \mathrm{m}\right), 3.24-3.19$ $(1 \mathrm{H}, \mathrm{H} 5 \mathrm{e}, \mathrm{m}) 3.72-3.69 \quad\left(1 \mathrm{H}, \mathrm{H}_{6}, \mathrm{~m}\right), \quad 4.19-4.15\left(4 \mathrm{H}, \mathrm{m}, \mathrm{CH}_{2} \mathrm{CH}_{3}\right.$ at $\left.\mathrm{C}-1\right), 4.27 \quad(1 \mathrm{H}, \mathrm{H} 1, \mathrm{~d}$, $\mathrm{J}=13.25 \mathrm{~Hz}), \quad 6.55\left(1 \mathrm{H}, \mathrm{d}, \mathrm{H}_{3}, \quad \mathrm{~J}=2 \mathrm{~Hz}\right), 7.59-6.96(8 \mathrm{H}, \mathrm{m}, \quad \mathrm{Ar} \mathrm{Hs}$ and thiophene protons $)$, 3.81(3H,s,Methoxy at phenyl ring). ${ }^{13} \mathrm{C}$ NMR (100MHz) ppm: 61.31(C-1 carbon), 193.05 (C-2 Carbon), 123.06(C-3 Carbon),156.91(C-4Carbon), 36.38(C-5 Carbon),39.14(C-6 Carbon) 168.93(Ester Carbonyl Carbon),60.83(Ester Methylene Carbon), 14.02(Ester Methyl Carbon),131.39-128.33(Ar and thiophene Carbons), 144.30,136.48(Ipso Carbons), 60.57 (Methoxy at phenyl carbon). Elemental analysis data: Calculated for $\mathrm{C}_{20} \mathrm{H}_{21} \mathrm{SO}_{4}$ : $\mathrm{C}=67.23$, $\mathrm{H}=5.88, \mathrm{O}=17.92, \mathrm{~S}=8.96$; Found: $\mathrm{C}=67.11, \mathrm{H}=5.76, \mathrm{O}=17.80, \mathrm{~S}=8.83$. MS: $m / z 357(\mathrm{M}+)$.

\section{Results and Discussion}

\section{Chemistry}

The synthesis of thiophene-2yl-1-aryl prop-3-ene-1-ones (1-4) was achieved through the versatile and efficient synthetic route outlined in Scheme 1. The Claisen-Schmidt condensation method for the synthesis of chalcones is very attractive since it specifically generates the trans(E) isomer ethyl 4-(thiophen-2yl)-2-oxo-6 aryl cyclohex-3-ene carboxylates (5-8) were synthesized by convectional and microwave irradiation method. The synthetic route of target compound is outlined in Scheme 2. 


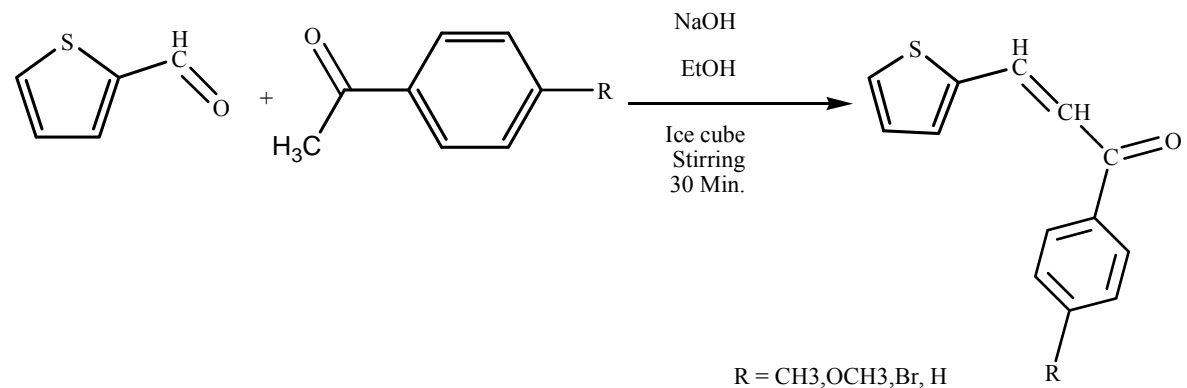

Scheme 1. For chalcone synthesis
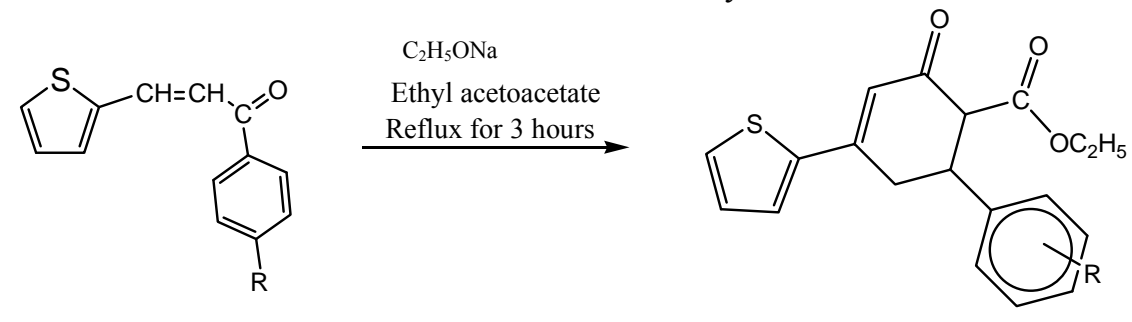

$\mathrm{R}=\mathrm{H}, \mathrm{Br}, \mathrm{CH}_{3}, \mathrm{OCH}_{3}$

Scheme 2. Synthesis of ethyl 4(thiophen-2yl)-2-oxo-6 aryl cyclohex-3-ene carboxylates

Chalcones with ethylacetoacetate and $\mathrm{NaOH}$ in ethanol under refluxing for 6 hours. In microwave irradiation method the reaction was carried out only in 2-15 minutes. Microwave irradiation method yield was high over conventional method. All the compounds were isolated in yields $(60-90 \%)$ and purified by crystallization from ethanol. The purity of the compound was established by thin layer chromatography (TLC) and elemental analysis. The melting point of the synthesized compound was determined on a MEL-Temp apparatus by open capillary method and is uncorrected. Structure of the synthesized compounds were confirmed by elemental analysis and spectral (FT-IR, ${ }^{1} \mathrm{H}$ NMR and ${ }^{13} \mathrm{C}$ NMR) data which were in line with the proposed structure. The reaction mechanism involves the formation of Michael addition product by ethyl acetoacetate with chalcones 1-4 in the presence of base, sodium ethoxide. Later the addition product undergoes intramolecular aldol reaction in the presence of sodium ethoxide base to give the title compounds (5-8). To discuss the spectral data of the synthesized compounds, methyl substituted compound 7 is choosen as the representative compound.

\section{Spectral analysis}

Analysis of FT-IR spectrum of ethyl 4-(thiophen-2yl)-2-oxo-6 methylphenyl cyclohex-3-ene carboxylates (7)

The FT-IR spectrum of the compound (5-8) afforded carboxylates Aromatic $\mathrm{CH}$ stretching $3060-3088.03 \mathrm{~cm}^{-1}$, the absorption frequencies around $1647.21-1654.9 \mathrm{~cm}^{-1}$ are due to $\mathrm{C}=\mathrm{C}$ group. The bands at $2924.09-2935.66 \mathrm{~cm}^{-1}$ are due to the presence of aliphatic C-H stretching vibration. The absorption band at $1732-1734 \mathrm{~cm}^{-1}$ are due to the presence of ester $\mathrm{C}=\mathrm{O}$ group.

Analysis of ${ }^{1} H$ NMR spectrum of compound (7)

The mass spectrum of the compound shows the proposed molecular formula of the compound 7.MS: $m / z 341(\mathrm{M}+)$. 


\section{Analysis of ${ }^{l} H$ NMR spectrum of compound (7)}

In ${ }^{1} \mathrm{H}$ NMR spectrum of compound, a triplet appeared at $1.28 \mathrm{ppm}(\mathrm{J}=7.2 \mathrm{~Hz})$ corresponding to three protons and this signal is due to ester methyl protons at C-1. A multiplet observed at 3.92-3.90 ppm corresponding to four protons and this signal is due to ester methylene protons at C-1.Three multiplets are obtained in the range 3.04- 2.98, 3.29- 3.24 and 3.70$3.66 \mathrm{ppm}$ and they are due to H-5a, H-5e and H-6 protons. The doublet at $4.17 \mathrm{ppm}$ $(\mathrm{J}=14 \mathrm{~Hz})$ has been assigned to $\mathrm{H}-1$ proton. The doublet observed at downfield region at $6.39 \mathrm{ppm}(\mathrm{J}=2.5 \mathrm{~Hz})$ is due to $\mathrm{H}-3$ proton. The aromatic and thiophene protons appeared as a multiplet in the range 7.66-7.08 ppm.

\section{Analysis of ${ }^{13}$ C NMR spectrum of compound (7)}

The ${ }^{13} \mathrm{C}$ resonance at $197.80 \mathrm{ppm}$ is assigned to $\mathrm{C}-2$ carbonyl carbon where as carbon resonance observed at $169.24 \mathrm{ppm}$ is assigned to estercarbonyl carbon. The ${ }^{13} \mathrm{C}$ resonance at 35.46 and $39.16 \mathrm{ppm}$ are due to the C-5 and C-6 carbons respectively. The ${ }^{13} \mathrm{C}$ resonance observed at 63.70 and $14.10 \mathrm{ppm}$ is assigned to ester methylene and methyl carbons at $\mathrm{C}-1$ respectively. The signal observed at $61.30 \mathrm{ppm}$ is assigned to $\mathrm{C}-1$ Carbon; where as the signal at $122.38 \mathrm{ppm}$ is due to $\mathrm{C}-3$ carbon. The aromatic and thiophene carbons observed in the range of $130.50-126.00 \mathrm{ppm}$. C-4 carbon resonates at $155.24 \mathrm{ppm}$. The remaining ${ }^{13} \mathrm{C}$ signal at $136.60 \mathrm{ppm}$ is due to ipso carbon. Replacing $\mathrm{R}$ group by $\mathrm{H}, \mathrm{Br}, \mathrm{CH}_{3}, \mathrm{OCH}_{3}$, gave corresponding products as shown in Table 1. As can be noticed from (Table 1) the products were obtained in good yield regardless of various electron donating and withdrawing groups present in the aromatic ketones.

\section{Lipinski's Rule}

The above synthesized compounds (5-8) obey the Lipinski's Rule of Five, because they have not (1). No more than 5 Hydrogen bond donors (The total number of Nitrogen-Hydrogen and Oxygen-Hydrogen bonds). (2) Not more than 10 Hydrogen bond acceptors (all Nitrogen's and Oxygen atoms). (3) A molecular mass of our synthesized compounds are not exceeding 500 Daltons. (Molecular masses of Compound 5- 326, Compound 6-406, Compound 7-341, Compound 8- 357). (4) Melting point of our synthesized compounds are not exceeding $500^{\circ} \mathrm{C}$ (Melting points of Compound 5- $90{ }^{\circ} \mathrm{C}$, Compound 6-80 ${ }^{\circ} \mathrm{C}$, Compound 7-130 ${ }^{\circ} \mathrm{C}$, Compound 8- $100^{\circ} \mathrm{C}$ ). (5) The log $\mathrm{p}$ value also not exceeding greater than 5 ( $\log \mathrm{p}$ values of Compound 5- 2.69, Compound 6- 4.68, Compound 7- 3.17 and Compound 8- 3.72). So the above synthesized compounds are obeyed the Lipinski's Rule ${ }^{13}$ of Five. Therefore our synthesized compounds (5-8) are drug molecules. The Values are shown Table 2.

Table 2. Lipinski's Rule for compounds (5-8)

\begin{tabular}{cccccc}
\hline Compound & $\begin{array}{c}\text { No. of } \\
\text { H-bond donors }\end{array}$ & $\begin{array}{c}\text { No. of } \\
\text { H-bond acceptors }\end{array}$ & $\begin{array}{c}\text { Molecular } \\
\text { mass } m / z\end{array}$ & $\begin{array}{c}\text { Melting } \\
\text { point in }{ }^{\circ} \mathrm{C}\end{array}$ & log p \\
\hline 5 & $<5$ & $<10$ & 326 & 90 & 2.69 \\
6 & $<5$ & $<10$ & 406 & 80 & 4.68 \\
7 & $<5$ & $<10$ & 341 & 130 & 3.17 \\
8 & $<5$ & $<10$ & 357 & 100 & 3.72 \\
\hline
\end{tabular}

\section{Conclusion}

In conclusion the reaction of thiophene chalcone with ethylacetoacetate in the presence of inorganic solid support (Sodium hydroxide) under Microwave irradiation resulting carboxylate 
derivatives (5-8) via Michal addition followed by an intra molecular cyclocondensation. This process has advantages over conventional methods, such as shorter reaction time, highly yield, solvent free and environmentally benign. The synthesized compounds may serve as useful intermediate for the synthesis of structurally diverse heterocycles. The structures of the synthesized compounds were confirmed by FT-IR, ${ }^{1} \mathrm{H}$ NMR, ${ }^{13} \mathrm{C}$ NMR and elemental analysis data, which were in line with proposed structure and also the synthesised compounds were checked by their drug ability using Lipinski's rule.

\section{References}

1. Motta L F, Gaudio A C and Takahata Y, Int Electro J Mole Des., 2006, 5, 555-569.

2. Awasthi S K, Mishra N, Kumar B, Sharma M, Bhattacharya A, Mishra LC and Bhasin V K, Med Chem Res., 2009, 18(6), 407-420; DOI:10.1007/s00044-008-9137-9

3. Cheng M S, Shili R and Kenyon G, Chin Chem Lett., 2000, 11, 851-854.

4. Lim S S, Kim H S and Lee D U, Bull Korean Chem Soc., 2007, 28, 2495-2497.

5. Bag S, Ramar S and Degani M S, Med Chem Res., 2009, 18(4), 309-316; DOI:10.1007/s00044-008-9128-x

6. Lahtchev K L, Batovska D I, Parushev S P, Ubiyvovk V M and Sibirny A A, Eur J Med Chem., 2008, 43(10), 2220-2228; DOI:10.1016/j.ejmech.2007.12.027

7. Yayli N, Ucuncu O, Yasar A, Kucuk M, Akyuz E an Karaoglu S A, Tur J Chem., 2006, 30(4), 505-514.

8. Begum N A, Roy N, Laskar R A and Roy K, Med Chem Res., 2010, 19, 1-14.

9. Kaushik S, Kumar N and Drabu S, Pharma Res., 2010, 3, 257-262.

10. Vasil'ev R F, Kancheva V D, Fedorova G F, Batovska D I and Trofimov A V, Kinetics Catalysis, 2010, 51(4), 507-515; DOI:10.1134/S0023158410040087

11. Sivakumar P M, Prabhakar P K and Doble M, Med Chem Res., 2010, 19, 1-17.

12. Vogel S, Ohmayer S, Brunner G and Heilmann J, Bioorg Med Chem., 2008, 16(8), 4286-4293; DOI:10.1016/j.bmc.2008.02.079

13. Lipinski's C A, Lombardo F, Dominy B W and Feeney P J, Adv Drug Deliv Rev., 1997, 23(1-3), 3-25; DOI:10.1016/S0169-409X(96)00423-1 